University of Rhode Island

DigitalCommons@URI

Open Access Master's Theses

1971

\title{
The Effect of Physical Activity and Emotional State on Aggression
}

Robert Steven Frazier

University of Rhode Island

Follow this and additional works at: https://digitalcommons.uri.edu/theses

\section{Recommended Citation}

Frazier, Robert Steven, "The Effect of Physical Activity and Emotional State on Aggression" (1971). Open Access Master's Theses. Paper 1629.

https://digitalcommons.uri.edu/theses/1629

This Thesis is brought to you for free and open access by DigitalCommons@URI. It has been accepted for inclusion in Open Access Master's Theses by an authorized administrator of DigitalCommons@URI. For more information, please contact digitalcommons@etal.uri.edu. 


$$
\begin{aligned}
& \text { SFH } \\
& \text { As } \\
& F+2 \\
& \text { C. }
\end{aligned}
$$

THE EFFECT OF PHYS ICAI ACTIVITY AND

EMOTIOMAI STATE ON AGGEESSIOI

BY

ROBERT STEVEN FRAZIET

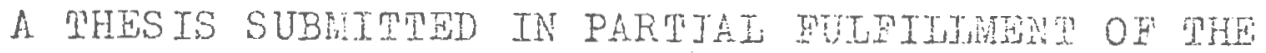

REQUIFTHETTS FOR THE DHGRE OF

MASTER OF ARTS:

IN

PSYCFOIOOGY"

UNIVERSITY OF RHOTE TSIATD $=5$

1971 
The poychological literature on hostitity oethersis contains tho versions which would predict different outconse of cathartic activity. Whe nost comron version of the catharsis hypothesis states that the performance of an agresesive act reduces the instigation to further agression, assuming that there is no adjltiona fruscretion. mhe decrease in frequency of agmressive responses is supposenjy due to the reduction of physiological or psycholosicel teision. The revfsed version of the catharsis hypothesis mantaing that angert must be present for the reduction fn ageression to occur while tre earlier cathersis hypothests states that any agressite activity vil]. rejuce subequent agrassion.

To test these hypotheses, four eroups of juvenile delinquents were tested In fow condtions. Two of the moups wers ancered, two rroups nonangered. One angesed group and one nonm angered group swan while the other two angered and nonangered groups ratched a neutral novis. Tho angered group minch swam shoved a signif jcant decrease in anger eni tendency to aegression. The methot usad to arouse arger in the sutgects ras fomin to be effectlve and lmpliogtions for further rescaroh vere disoussod. 
I wish to express my sincere thanis to the many people who made this research possible. I am graterul to the phode Island Training School ont fr. Josewh Devine who allowed the to conduct my studies at the training school, as well as the many staff members who helpea me in solving the proctical. problems of runing the experinent.

I am especially grateful to the merters of my thesis committee who devoted nary hours of their time to helping me, my comnittee chairman Dr. Albert J. Lott and Ir. James Prochaska, Fr. Allan Ecimen and Dr. Afred Yascale. 
Page

ABSTRACT $\ldots \ldots \ldots \ldots \ldots \ldots \ldots \ldots \ldots \ldots \ldots \ldots \ldots \ldots \ldots \ldots \ldots$

LIST $O F$ TABLES .......................

CHA PTER

I. INTRODUCTION. . . . . . . . . . . . . . . 1

II. MEHHOD........................ subjects

Inventories

Frocedure

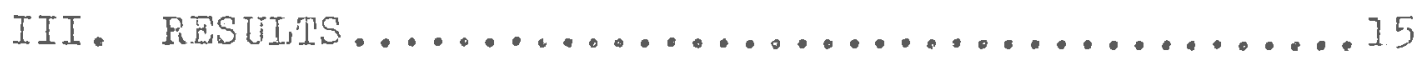

IV. DISCUSSTON...........................

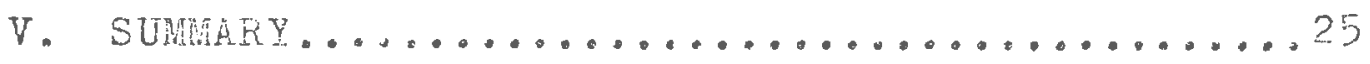

APPENDIX A......................., 26

ADPENDIX

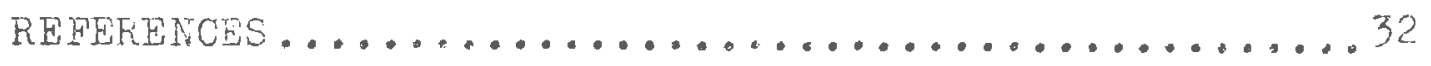




\section{LIST OF TABLES}

Table

1. Means of Buss-Durkes Mostility scores

for Subjects in Four Fyperinental Conditions.....

2. Summary of Analysis of Variance for Buss-

Durkee Scores for Four Experinental

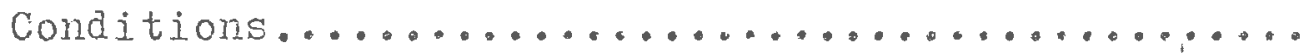

3. Mean Ages (in years) of subjects in Four

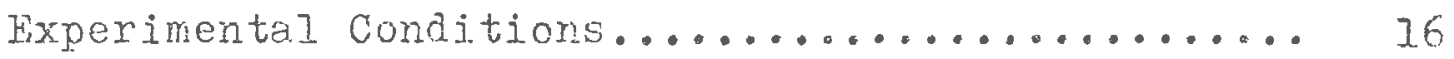

4. Summary of Analysis of Variance for Ages

of Subjects for Four Experimental conditions..... I6

5. Means for linnesota Clerical lest scores for

Four Experimentel Conditions................ 16

6. Means for Pretest and Posttest MACH Scores

for Four Experimental Conditions............. I7

7. Neans for Change Scores on MAACL for Four

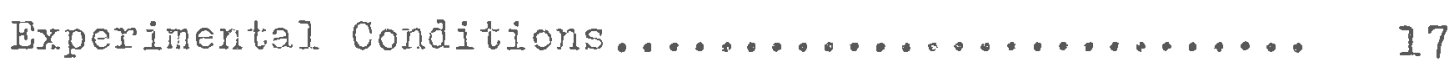

8. Summary of Analysjs of Variance for MAACL

Change Scones for Four Experimental Conditions.... 18 
CHAPTER I

\section{IHTKODUCTIOH}

The present experiment studied some aspects of the hostility catharsis hypothesis. More speclficalyy, it investigated the effect of physical activity ard state of emotional arousal on a person's tenoency to aggress. The most common version of the cathareis hypothesis in the psychological litersture meintains that performenoef ar aggressive act reduces the instigetion to further eggresion, assuming that there is no further frustration. This decrease in the frequency of aggressive responses is supnosediy due to the reduction of physiolocical or psychological tension. Orthodox psychoanalysti, together with Dollard and his colleagues (1939, p. 50) jrast that exyression of aggres sion results in at least a morentary reaction of irstigetion to aggression regardess of the nostile act's effectiveness in removing the obstacle to the goal directed activity. Wha expression of afgression is celied "catrersis" ard the diminution in tendercy to aggress as a consenuenco of such expression of aggression is called the "eatharijo effect."

Dollard, Doob, Miller, Howrer and Sears (1939) defired it in this way: "rhe expression of an act of ageression is 
a cathaxsis that reduces the instigetion to all other acte of aggression." The largery negrive Experimental firdings (e.g., Bandura \& "HaItens, 1963; Eerkowice, 1962), howerer, have led to a change in the original statemert. Suss (1961) and Feshbach $(1961,1964)$ contend that the cathartic or drive-reducing function of behavior onjy occurs under cextain specified conditions. This revision grev out of the work on modeling of aggressive person stimuj. Hitnessing tire behavior of an ageressive model supposedly produces decrenerts in subsequent aggression when the observer has been ageres sively aroused at time of exposure to the model. If, on the other hand, the observer's aggressive drive has not been. activated during the period of vicarions perticipation, such exposure augments ensuing aggressive responses. The reviseg catharsis hypothesis thus presupposes that functional properties of modeling stimuli can be radicaliy altered by trensitory emotional states of the observer.

The main difference then, betweer the old and new catharsis hypothesis is that the first predicts catharejs after the performance of any aggressive act, assuning there is no further frustration. The revised hypothesis requires presence of anger arousal in the subject for cathanjs to take place. Without anger arousal, the perforraves of the aggressive act, or obscrvation of another pexioring such an act, increasen the likelinood of increscor aggression. Stuales on canasis with and winout anges arousal (Kenny, 1952; jeshoach, 1956, 1958; 5uss g. Foljart, I95e) 
show that, in the absence of angey, vicarious expression of aggression increases the tendenoy to aggress and in the presence of anger, vicarions ageression decresses the tendency to aggress. Hornberger (1959) jnsulted his subjects to anger them and found no difserences between angered and nonangered subjects in either fantasy or physical catharsis. Feshbach (1955) also used insult and found thet the effect. of telling aggressive stories in the presence of anger was to lower the tendency to aggress. Thibaut and coules (I952) used insulting notes to anger their subjects but found no differences between experimental and control groups. The explanation offered was that the experimertal subjects had only minjmal opportunities to cathart. Fosenoaun and Dechamm (1960) followed up the Thibaut and Coules study. They were unable to anger half of their subjects using an insul torow cedure and the results from the other half of the suojects who were angered could not be explained by the catharsis hypothesis. Pirojnikofi (I958) folnd that with insulted subjects the catharsis group had higher aggression on an attitude questionraire than the control group. Most of the above mentioned studies found no difference hetween angered and nonangered groups rather than an increase in ageression in the cathrseis group. A videspread proolem in etuoies of this type has beor the difficul ty in arousing anger as well as demorstrating that anger has been aroused in ajl the subjeots mo were supposed to have been angered. The rajority of the studies revievod show inconsistent 
results. One of the factors that might acoount for the inconsistency is the sirce anger is only a transient resction, time js an important varjable ir catharsis (3uss, 1961). Anger slowly dissipates mether or rot ageression occurs, and as the tension state of anger dminishes, the tendency to aggress also diminishes. Where is a cethertic effect only so long as anger is present; when surfjeient time has elapsea for anger to subside, there is no jorger the possibility of a cathartic effect. Since angex is an enotional response, the cathartic effect nust involve a lowering of poysiological tension. Buss (196i) stated thet no study hes measured the effect of an aggressive responee on the suject's physiola.. gical state, and such a study would seem to be ar importert step in the investigetion of catharsis. A later study by Hokansor (1963), howerer, found that amone frustreted subjects the expression of aggression directiy to the frustrator rem sulted in a sierificant degree of "physiological teneion" reduction as measued by diastolia blooa presoure (Dep). Baken (1957) found that overt ox airect commuication of counteraggression to the instigetor was the nost effective way of achieving phyjological reduction or tension as measured by decreases in DBF.

If a catroxsis takes place when an at of aggression is expressed it secms lirely thes the area of competitive sports woula be one place to study the effects of canarsie. Berkowtz (1962) attempted to demonetrate the nete for an exanination of lite effeots ot convetive soopts on the 
instigation to esgressicn. He strted thet, iespite the lack of data, or perhaps because of it, many psychietrists, psychologists, and recreatson leaders instst that competitive athletic contests provide a necessary release for pent up aggressive impulses. Berkowitz gives an example of this view as expressed by two prominent psychiatrists speaking within a few years of each other on the topio of mental health. Both G. E. Gardiner (1952) and William heminger? (1948) stated that play brings about a needed release from tensiors created by "instinctive" agriessive impulses.

Two studies of aggression in college students attempted to relate TAT aggression to athletic activity. Husman (1955) had boxers, vrestlers, cross-country runners, and nonathietes take the TAT before and after the athletic season (not immediately before and after an athletic contest). The TA protocols were scored for both anount and direction of aggression. The amount of aggression increased from before to after the season in all the athletes but not in the nonatiletes. It may be assumed that all the athletes were reinforced during the season in that they received praise and perhaps, victory and the increased habit strength was reflected in their higner postseason TMI aggression scores.

The boxers had significontiy less TAT aggression, in general, than the other three groups. One colld argue that the low aggression of the boxems indicates thet theic agures. sive urges were being oraired off dy argressive athletic activity, assuning that boxine is nore agexessive than 
wrestrirg or track. However, î́ this ware correct, the boxers' 'Ml agstession frum befoxe to afuer the season would be lowered like the cther athletes. It might be fruitiul, according to Buss (1961), to regand the boyers as being more aware of the intensely agsressive nature of boxing and defensive about their om aggressive tenderoies. Ihis would lead to a decrease in the amount of MA ageression and to a greater turning inward of $14 \mathrm{I}^{2}$ agression, both of which occurred in the boxers.

The stuay by stone (1950) investigated TA aggression in football players and matched controls but obtained diferent results from those of Husman. Durjng the seasor, athietes and nonathletes did not differ in ir aggression, but deter the season the football players showed signifjcantly less aggression on the MAT. There are several difficulties in interpreting these results as supporting oi not suporting a catharsis hypothesis. First of all, it is possibie that anger. is more a part of football than other sports and so one might find a cathartic erfect in football but not in boxing, wrestling or running. Since the investigators did not measure presence of anger in any of the athletes it is impossioje to te11. A second probleni is that the studies ware on erfects over a full athietio season rather than imnediately after a. game which would be nore appropinate for measuring a possible cathartic effect. Finally, in both studies the rensor who scored Thi protocols knew when they hed been adrjnistered, and there may have been unconscious oia ir sooring for 
aggression.

Ryan (1970) used numer of tines a subject administered shock to another person as a dependent variable and concluded that vigorous motor activity was not an effective means of lessening aggressive tendencies. However, Ryan failed to demonstrate that the subjects in his anger conditions were actually angered and he ray not have allower sufficientidine and opportunity to engage in enough physical activity (the cathartic activity was ten blows with a hamer) for his angerea subjects to cathart even if they vere actually angered. Since there is so little experinentel research in the area, it seems that a study on the innediate effects of physical activity on the lessening of aggressive responses would be a valuable addition to the fielo of aggression research. If cetharsis takes place when a tension reducing type of behavior is performed, then an activity which reduces tersion should effect a catharsis. Assuming that physical activity reduces physiological tension, a person's tendericy to aggress and the accompanyjng physiological tension should be reduced by physical activity according to the early catharsis nypothesis, The later catharsis hypothesis states that there must be angex in order to produce a reduction in tension and if there is no anger present, the level of aggression should remin the aame. Since the present study used adolescents as subjecte, it is important to look at the results of a group of studies investigating aggression jn arolescents. Since these studiea used the mat to measlite ageression, it is also possibje to 
comment on the uaefuness of thie testing instrument with this particular population. The results of studies by riller (1953), Heymann (1955), and Jensen (1957) that attempted to relate TAT indicos of fantasy aggression to behovioral aggression were inconclusive. OnIy ore study (mussen and Naylor, 1954) found a positive relationship betmeen overt and fantasy aggressive behavior. So it seems that although the Tin is a useful. indicant of aggressiveness in other populations, it appears to be of little use in assessing aggressiveness in adolescerts.

The adolescents used in the present study vere juvenile delinquents detained at the Rhode Islard Training School for Boys (RITSB). Since sports are usea as part of the rehabilitative treatment program, the results of this study may be helpful in evaluating the effect of physical activities on the tendercy to aggress. These youth are considered to be generally more aggressive than a normal population of adolescents.

In the present study, two inventories were used to measure the level of agression and hostijity that existed in the subjects. One of these, the Buss-Durkee (1957) invertory, is more of a trat measure of aggression, i,e., a measure of a subject's general and more stable level of aggression. The Wultiple Affect Arjective Check List (MACL) (Zuckeman, Ha, Iubin, B., VogeI, L., \& Vajeribus, 1964) is a state measure of agercosion, i.e., a measure of how 
aggressive a sujiect feels in the present situation (spielberger, 1966).

Two independent variables ware investigated; presence or absence of physical activity and cmotiones stalie of subjects. The physical activity was suming and the subjects were either experimentaliy angered or nonangered. The boys in the residential cottages at the RInSB swim at least once during the week. The two experimental swimming groups vere run on the night that they oxinawijy went to the gymasium to swim. Ihis was done to keep the experimental conditions as close as possible to the real life conditions at the Trajning school. Thus, by being in a natural. setting, the subjects are less likely to nonitor their responses and may be more sportaneous in their behavior.

The dependent variable was the difference between the pretest and posttes $M A A C L$ scores. The hypotheses to be tested were that:

1) Angered subjects who engage in swinring will decrease in their tendency to aggress more than angered subjects who viewed a neutral move.

2) Angerea grouve, jn gereral, will show a decreased tendency to agress following either swiming or movie viewing when compared with nomangered growps.

3) Nonergered subjects who engage in either swimirg or movie riewing will not change-significantly in their tendency to aggress. 
CHAPTHR II

NELHOD

Subjects

Seventy delinguents from the Rhode Island Training School for Boys (RITSE) participated in the study. The boys ranged in age from 13 to 18 years. The population contained both Caucasian and Negro youths fron a predominantly lower class socio-econonie background.

\section{Inventories}

Buss-Durkee Hostiliby Inientory. Hostility inventories typically are of the self-report variety with the content of the items being unajsgused. The Euss-Durkee is the most commonly used inventory for measuning the trait of hostility. It is used to get d. measlire of a pexson's tendency to be hos tile in centeir situetions. The Buss-ourkee Hostility Inventory consists of 56 iteme in questionnaire form which subjects mark $T$ (true) or $F(f a l s e)$. Whe itens are seifmreoort items which concen the way subjects generally jenare ju certain situations where they may or may not perceive their actions to be culturally unacoepteble. The scoring yields sever subclasses of hostile, agsressire cengrio as well as a total suming hostizity score. Mhes atud used the sumery soore.

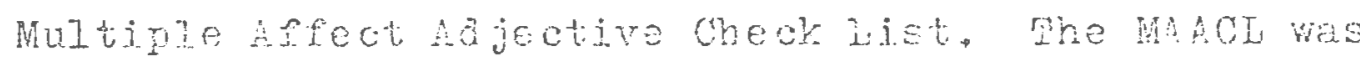


designea to fill the ned fon a selfuarinistened test which would provide veljd measures of three of the clinicolly relevant negative affects: arxiety, Repression and hostijity. The MAACL, as the rame inplies, is a list of 89 adjectires which the subject is asked to consider and check if he reels that way. Items checked are scored plus and items not checked are scored minis. This test grew out of the Affect Adjectivo Check Iist (AACL) measure of arxjety which was developed by Zuckerman (1960) in response to a need for a best instrument designea to measure changes in verbalizable "anxiety". The AACL was expanded by adding scales for depression and hostil... ity by zuckerman, et al. (1964). qhe reliabjlity correiations reported show a predicteble pattem of high internal reliabil ity coefficients $(.90)$ and low test retest correlations (.15) for the Today form of the test. This form instructs the subjects to answer as they feel "right now" and one would not necessarily expect sigrificant correlations between how a subject feels "right now" ard how he feels at some later time. The Buss-murkee MACI hostility scores coricelated signifjecntiy with a questionneire measure of hostility (.67) and TeT hostility scores (.48). Cther data have becn reported wich attest to the instrument's high reliability and validity (Zuckerman, Ir Irbin, 2965).

Zuckernan and Iubin (1955) report that tho important response sets, sociel desinulity ane acquicscence, do not appear to be important incluencos ir the matid and partiolarly not in the godey fonm of these tests. Zuekerman and 
Lubin also sugests that the maor is valuable for stress experiments requjing before and after measures of effect.

Minnesoto Gerical Test. The Mimesota Mlerical Test (MCr) consists of a series of sets of numbers (Andrew; Peterson, \& Longstaff, 1933). The subject is instructed to make a check marl on the line between the rumbers if troy are exactly the sene; if they are difrerent, no mark is made. The instructions stress the need for speed and accuracy. Subjects are told to work as fast as possible without maring mistakes. The normal time linit is seven minutes. The subjects in the present study will be allowed three minutes.

\section{Proceduxe}

Since there vere four cottages at the RITSB and approximately 20 boys in each cottage, these four cottages were used for the four experimertaj. groups. The two activity groups swam while the two control groups engaged in a neutral bask (watching a movie). One activity group and one control group made up the two angered groups. The other two groups nade up the nonangered groups. The design is represented in Figure 1.
ACTIVITY
(Swiming)
$N=19$
$\mathrm{N}=16$

CONTPOL

(Novie Viening)

$N=] 8$

$N=17$

Fig. J: A represcntation of the indegendent variabs interacting in a factorien design. 
Ono week before the erierimentel sessions, the subjects were adminjstered the Buss-Durke Iostility Inventory. Ihe Buss-Durkee scones were used to detewrine whether or not the groups differed in initis agressive terdencies. At the beginuing of each experimental sessum ore veek Iater, the groups took the mirnesota Gierisal Dest (MCT) but with different instructions to the angered and nonangered groups to begin the experimental mangpulation of anger. The two angered groupe were told at this point that they would receive a reward if they did well. on the Mcre After the vor! was adminjstered, the argered groups ware required to wajt in silence for five minutes while the tests vere corrected, ard they were told that they dja not succeed and would not get the promised revard. The anger instructions also irciu. ded the experimenter expressing his own anger and aisapoint... ment to the subjects for their por performence. Care was taken to employ an experinenter who was a stranger to the boys, and so, jnitijliy at least, could oe peroeived by the subjects as a newtra figure. Vejbetim accomis of the anger and nonangered instructions and a sumery of the nrocedural steps mey be found in Appendix A.

A.Iter the suojects were angered, they took the Mulipie Affect Adjective Check List (MACT) as a pletes mecsure of the effect of the anger instructions. One group then vent to the gymasium for the swimming wile the cortrol group welched the novie. The movie used for this stuiy bas beer rated with respect to iss aegessive and hostile cortert. 
The film, "Alasira, tand of Promiso", was jucked to be a neutral simulus by throe retero who have wonked closely with boys at the RIJSB. The nongngered groups took the MAACI five minutes after the HOi but were not piomiseo a reward and not deliberately angered. The purpose of the five minute delay was to equate these two groups with the angered groups who also had to wait five minutes between the MACL and MCI. The postiest MAACL was aministered to all groups after the physical activity or movie. The time interval between pretest and posttest maCI were the sarre for all groups, thirty-five minutes.

tach suoject produced a pretest and postuest score on the MACI. The difference detween the MACI scores for each subject is the score considered in the aralysis of group differences. A two way analysis of variance for unequal n's was employed to test the dirferences among the groups. In order to minimize the effect of the adjectives cinecked on the pretest MACI with the postest MACI, the experimenter stressed that the subjects should focus on how they feli lat this moment" and not try to remember how they answered before. At the end of the study, all Ss were rewarded, praised, and the purpose of the experiment explained to them. 


\section{RESUTSE}

To test injtial djferences in hostility, the BussDurkee scores (Hostility Invertory), wore arialyzed for the four groups. The means of the Buss-1urkee scores are shown in Table 1. The subjects' scores ranged rron a low of 15 to a high of 75. Table 2 presents the resultis of a one-way analysis of variance comparing the means presented in wahle 3. It car be seen that there were no significant differences anong the four experimental groups in their ingtial jevel of hostility as measured by the Bussmurkes Hostility Irvertom.

\section{TABIF 1}

MEAIS OF BUSS-DURREA HOSPILITY SOORS

FOR THE FOUR EXPERIMENTAL CONDITIONO

\section{Angered Noriangered}

Swiming Movie
37.5724

4]. .2142
43.2250

42.7994

\section{TABIIS 2}

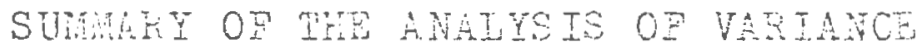

FOR BUSS-DUREEE HOSTIITIY SCORSS

FOY FOUR EXPEALENAA, CONHTIONE

\begin{tabular}{|c|c|c|c|c|c|}
\hline Source & $S S$ & $d \hat{t}$ & $\mathrm{MS}$ & $F$ & $\underline{p}$ \\
\hline $\begin{array}{l}\text { Totan } \\
\text { Between } \\
\text { Within }\end{array}$ & $\begin{array}{r}5,053.50 . \\
289.009 \\
4,763.695\end{array}$ & $\begin{array}{l}E 2 \\
5 \\
59\end{array}$ & $\begin{array}{c}96.635 \\
80.740\end{array}$ & 3.206 & - \\
\hline
\end{tabular}


HEAH AGES IN YEARS OF SUJPCHS IS

FOUR RXPEIMENTLL COMDITICNS

$$
\text { Angered Nonshered }
$$

$\begin{array}{lll}\text { Swiming } & 15.3157 & 15.9528 \\ \text { Movie } & 14.7777 & 13.8695\end{array}$

TABIE 4

SUIMARY OI ANAIYSIS OF VARTANOE FOR AGES

OP SUBJECTS FOR FOUP EXEERTMEHTAL

CONDITIONS

\begin{tabular}{|c|c|c|c|c|c|}
\hline Source & $S S$ & $d f$ & 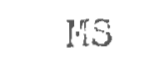 & $\mathrm{Y}$ & $\underline{p}$ \\
\hline $\begin{array}{l}\text { Total } \\
\text { Between } \\
\text { W1th1n }\end{array}$ & $\begin{array}{r}280.899 \\
23.440 \\
257.4 .59\end{array}$ & $\begin{array}{r}78 \\
3 \\
75\end{array}$ & $\begin{array}{c}7.813 \\
3.432\end{array}$ & 2.27 & - \\
\hline
\end{tabular}

Table 4 represents the results of a oneway analysis of varlance comparing the means presented ju Table 3. There are no slgnificant differences anong the subjects' ages in the four experimental groups. On the Mrmesota clerical lest the results of t-tests comparing the means of the two angered groups, the two nonangered groups and the angered versus nonangered groups revealed no sigrificant ifferences between these groups.

TABIE: 5

MEAMS FOR HINHESOTA CTATICAL TEST SCORES FOR FOUA EYPEZIEERRI COEITIOES

\begin{tabular}{lll}
\hline & Angered & Monengered \\
\hline Swiming & $1 ? .7368$ & 16.0625 \\
Hovie & 18.8333 & 15.7058 \\
\hline
\end{tabular}


MEN NS FOE PEETEST AND EOSTRESP MACL SCORES FOR FOUR LXPEIMEITAS CONDITTONS

Angered Nonangered

Swimming

$\begin{array}{llll} & \text { Pretest } & 15.736 & 10.812 \\ \text { Novie } & \text { Postest } & 12.684 & 10.937 \\ & \text { Pretest } & 14.944 & 12.170 \\ & \text { Posttest } & 13.722 & 11.411\end{array}$

TABIE 7

MEANS FOR THE CHANGE SCORE ON MAACI FOR HOUR EXPGRINANTA CONDITIONS

Angered

Nonangered

Swimming

Movie

7.0526
5.2222

3.8750

4.7647

A t-test comparing tine means of the pretest MACI scores for the angered versus the nonangered groups showed a difference at the .001 level of significance $(t=4.48)$, with the argered groups being significantiy more hostile than the nonangered groups. An analysis of the pretest scores for the two angered. groups found no significant differences, nor was there a significant difference between pretest scores of the nonangered groups. Whe resujts of t-tests comparing the pretest and posttest means for each of the four groups separately showed a significant difforence onlybotween the means of the engered 
swiming groups, with tie rattert score being lower (less hostile) than tive pretest scores.

Table 7 shows the means for the chenge scores for the four groups. A change score was obtained for each subject by subtracting the posttest ind score from the pretest MAACI score ana adding a constant of t4. The addition of the constant vas necessary because in some cases the posttest score was larger than the pretest score ard a regative number was obtained from the subtraction procedure. The adation of a constant number $(+4)$ insured that the lomest possible score a subject would have was rexo, and thus the higher the change score, the greater the reduction in anger. The highest change score a subject obtaired was 13, his absolute score being 9.

\section{TABLE 8}

SUMARY OR ANALYSIS OF THE VARIANCH FOR UAAGL CHA HGE SCORES FOR THE FOUR EXPHRTHETISI CORDIPIONS

\begin{tabular}{lrrrrr}
\hline Source & SS & DF & MS & $F$ & $\underline{P}$ \\
\hline Total & 506.70 & 69 & -5 & - & - \\
Emotion (IS) & 58.34 & 1 & 58.34 & 9.37 & .005 \\
Activity (A) & 5.30 & 1 & 6.30 & 1.01 & - \\
EX A & 31.79 & 1 & 31.19 & 5.01 & .05 \\
Error & 410.87 & 66 & 6.22 & - & - \\
\hline
\end{tabular}

These results show a significant difference for anger and a significart interection efiect. Thus, the two angered groups had signjicanty higher MACJ scores than the nonangerea groups. This indicates thet there vas a gleater 
reduction in arger for the ancered grougs in the half hour between MACI pretest and postrest than there was for the ronangered grolps, berause the higher change score indicates a greater reduction in arges.

There is evidence, from the fact that a significant interaction effect wes obtained, that a subject in the angered swiming group showed the greatest reduction in anger of the four groups. The next largest reduction occurred in the angered movie group. It is interesting to note that the mean changes score for the nonangered swiming group is less than 4. Considering the addition of the constant (4), this suggests the possioility of a slight increase in anger following swiming when a subject was rot aggressively eroused.

The results of t-tests compaxing the means for the Made charge scores show a significant difference betweon the angered and nonangered swimming groups ( $p .01$ ) but no other significant differences were found. 
CHAPTEE IV

\section{DISCUSSTON}

The results of this study are rathor complex. On one hand, physical activity, in the form of swimmirg, appears to produce a catnartic effect since the engered swimirs group showed a greater reduction in anger than the nonangered swimming group. However, if swiming alore was acoounting for the cathantic exfect, then the angered swiming group should have reported significanty greater reduction in anger than the angered movie group, but this was not the case. Therefore, the results suggest that swimming, combined with the passage of one half-hour of time, seems to be the variable producing a significant cathartic effect. This conclusion would further explain the significent interaction found in this study. I'he passage of time alone was not enough to produce a signjificent; cathartic effect since the angered movie group did rot report a greater reduction in anger than the nonengered movie group.

It seems from the findings that, since the angered gmoups reported significartly greater anger reduction, emotional. arousal is the important variable in cetharsis, The resuts of this study support the predictions of the revised cathersis hypothesis (Buss, 1961; Reshbach 1961, 2964; Berkomtu, 1962; 
Bandura \& Walters, 1963) which stetes that there rust be anger in order to produce a reduction in tension. The eariy catharsis hypothesis is not supported becase there was no significant tension reduction in the nonangered groups. The physical activity of swiming apparently redured the tendency to aggress, perhaps by reducing the physiological. tension accompanying the acggressive tendencies.

In order to discuss a cathartic effect it is important to demonstrate that the angered groups were actually angered. This is especially important because of the failure of previous studies (Thibaut \& Coules, 1952; Rosenvaum do de Chaxms, 1960; kyan, 1970) to demonstrate that their subjects were really angered before the experimontal. menipulations designed to produce a cathertic effect were performed. The fact that, in this study, the pretest MACI scores of the angered groups were significantly higher than those of the nonengered grolip provides support for the statement that the anger instructions were effective in angering the subjects.

To be confident that it was the anger instructions that worked and the subjects were not already angry at the time of the experiment, it is important to look at the results of the trait measure of anger, the Buss-Durke Hostinity Inventory. The subjects' initial level of hustility might have influenced the outcome of the experiment and possibly contaninated tive results. If one group of boys was more hostile and angry than another, then it is logical to assume that they would have scored highor on a measure 
of anger such as the hlacI than a less angry group of boys. Since the mAMCI was administered giter the experinental manipulation of enger (consisting of the subjects' frustram tion and the anger instructions) it was important to vake precautions against initial levels of anger or aggressive tendencies having an influence on the pretest MACJ measure. The finding that the groups were not different in initial level of aggression, i.e., no significant differences in the subjects' Buss-1)urkee scores, provides further support for the statement that it was the anger instructions that resulted in the angered groups being more angry than the nonangered groups. since these instructions produced demonstrable anger, they may be useful in future studies which need to provoke anger in their subjects.

A finding of additionel importance is that pretest Wricil scores of the arserea groups were not significently disrerent, indicating that the two groups were equally angereo. In addition, the pretest $\mathrm{MACI}$ scores of the nonangered groups were not significantly different suggesting that these groups also were less angry than the two angered groups. These results further suggest that the experimental manipulatjons were carried out in a standardized, consistent way for the four groups.

Another varieble that could heve contaminated tine results was age but the groups wexe found not to be significantiy different in average age of the subjects. Still anothex variable that might have afiected the results was motivation. Since the Mcr vas acministered to the subjects in the sngerea groups after they were promised a reverd for doing woll, the 
results of the Mor might b considered a crude indjcator of the subjecte' motjvations to do well on the tesk. It is possible also to see the lfor scores from the nonangered groups as inaicators of their motivation to perform on the task and cooperate in the experiment. If this way of looking at the MCT scores is valid, then the finding of no difference among the four groups on the MCr provides support for the statement that the four experimental groups did rot differ in initial level of motivation for performance in this experiment. When this is considered, along with the findings that there exists valid reason to treat the groups as independent with regard to at least some of the variables which might have necessitated matching the subjects or employing an analysjs of covariarce technique.

Although time is an important veriable in catharsis, according to Buss ( 1961 ), in this study it was the interaction of time ard physical activity which produced the cathartic effect, time alone did not. This suggests thet a future study, manipulating the effects of time, would be a valuable addition to the research literature. By shortening and lengthening the anounts of time during which the physical. activity is performea and by providing appropriate control groups it should be possible to discover a leneth of time which would be sufficient to allow aneer to aiseipate witrout a physical activity being performed. Also, since it is impossible to have subjeots engege in a physical activity winout the passage of time, it rould be helpful to find a point 
at which the meximum is reached, i.e., where the most anger is reduced by swimming and not by time alone. fnother implication from this study is that cuture studies, investigating the cifect of aggressive activities and competitive sports in reducing a person's tendency to aggress (e.g., Husman (1955); Stone, 1950) must control for the effects of physical activity alone. 
CHIPMER V

SUMHAY

While the results of this study are rather complex, it is clear that the physical activity, swimming, combined with the one half-hour of time produced a cathartic effect. Time alone dia not produce a catharsis, but future studies investigating the effect of greater amounts of tine may be suecessful in demonstrating that anger does dissipate over a period of tine. The combination of passage of time and physiological tension reduction was effective in producirg a cathartic effect. Future studies are cautioned to control for effects of physical activity wher investigating the effect of competitive sports and aggressive activities on catharsis. The anger instructions developed to produce anger in the subjects for this experiment were found to be effective.

The hypothesis that angered subjects who swim would decrease in their tendency to aggress more than those who view a movie was not supported. The hypothesis that angered subjects would show a greater reduction in anger than nonangered subjects was supported as well as the hypothesis that nonangered subjects would not change signiticantly in their tenaency to ageress. 
APPENDIX A

ANGER INS IRUCPIONS

Steps for Anger Conditions

relI subjects: "O.K., there are two tests for you to take. This next test is a harm one. I want you to try your hardest and, if you do well, you will get a reward. This is a good reward so I am sure that you will want to try your hardest. I am sure that you will do well on this test."

Hand out MCT sheets face down. Read instructions to subjects. When everyone has a sheet and understands the instructions, tell them to turn the paper over and begin. Allow subjects three minutes. Collect Mor.

Take papers up to desk at front of room. lell subjects to remain silent. Spend five minutes looking at the MCr papers and pretending to correct them. Tell subjects: "well, you guys didn't even try on this. You really screwed it up. I gave this same test to kids at a Massachusetts training school and they did twice as good as you. I am really pissed off at you guys for doing such a lousy job so you can forget about that reward I promised you. You didn't try so just forget about it. Here, take this test and get out." Expand and paraphrase instructions.

Hand out 1 AACI - instruct subjects to mark how they feel right now.

After swimming or movie is over hand out MAACI again. Instruct subjects to check the adjectives that describe how 
they feel at this momont and not by and remember how they checked their before.

E Steps for Nonangei Conditions

1) Hand out mor, face down and read instructions making sure instructions are understood. Have subjects turn paper over and begix. AIlow subjects three minutes to work. Collect Mor and spend five minutes pretending to correct them.

2) Hand out MACI. Instruct subjects to check the adjoctives that describe how they feel right now.

3) After swimming or movie re-administox MAACI. Instruct subjects to check adjectives that describe how they feel at this moment and not to try and remember how they checked it before. 
APPENDIX B

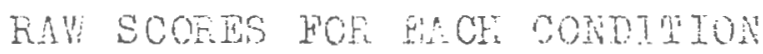

Angered Swimming Group

NiACI:

$\underline{S}$

BussaDurkee

Pretest Postest

1

2

3

4

5

6

7

8

9

10

$1]$.

12

13

14

15

16

17

18

19
37

44

40

33

28

32

15

50

$3]$

22

56

54

55

29

37

37

38

37

38
14

14

13

36

12

14

12

10

7

20

74

18

17

15

8

I.

17

16

13

] 3

].8

9

21

12

15

13

18

18

14

II

12

8

1.9

17

I].

16 
Nonangered Swiming Group

\begin{tabular}{|c|c|c|c|}
\hline \multirow[b]{2}{*}{$\underline{S}$} & \multirow[b]{2}{*}{ Buss-Durtee } & \multicolumn{2}{|c|}{ MAACE } \\
\hline & & Pretest & Posttest \\
\hline 1 & 47 & 10 & 12 \\
\hline 2 & 52 & 15 & 9 \\
\hline 3 & 44 & 3 & 3 \\
\hline 4 & 39 & 6 & 8 \\
\hline 5 & 38 & 6 & 10 \\
\hline 6 & 30 & 10 & 11 \\
\hline 7 & 43 & 8 & 9 \\
\hline 8 & 22 & 24 & 12 \\
\hline 9 & 50 & 12 & 13 \\
\hline 10 & 46 & 13 & 12 \\
\hline 11 & 42 & 14 & 13 \\
\hline 12 & 52 & 8 & 12 \\
\hline 13 & 50 & 13 & 15 \\
\hline 14 & 49 & 14 & 12 \\
\hline 15 & 42 & 16 & 12 \\
\hline 16 & 44 & 11 & 1.2 \\
\hline
\end{tabular}


Angered Hovie Group

$\underline{S}$

Buss-irukee

MACL

Pretest Postitest

1

40

15

1.4

2

43

18

i9

3

40

15

17

4

40

16

15

5

43

21

20

6

45

II

7

50

18

15

8

38

1.8

12

9

29

16

16

10

34

14

13

11

29

9

II

12

43

19

17

13

51

8

8

14

53

34

13

15

41

10

10

16

41

20

20

17

4.

11

9

18

41

15

II 
Nonangered Movie Group

\begin{tabular}{|c|c|c|c|}
\hline \multirow[b]{2}{*}{$\underline{S}$} & \multirow[b]{2}{*}{ Buss -Durkee } & \multicolumn{2}{|c|}{ MAACT } \\
\hline & & Pretest & Posttest \\
\hline 1 & 41 & 15 & 15 \\
\hline 2 & 43 & 11 & 11 \\
\hline 3 & 37 & 11 & 10 \\
\hline 4 & 42 & 14 & 14 \\
\hline 5 & 48 & 10 & 10 \\
\hline 6 & 40 & 12 & 11 \\
\hline 7 & .54 & 12 & 12 \\
\hline 8 & 37 & 13 & 13 \\
\hline 9 & 42 & 15 & 13 \\
\hline 10 & 52. & 10 & 12 \\
\hline 11 & 53 & 15 & 11 \\
\hline 12 & 45 & $1]$. & 9 \\
\hline 1.3 & 43 & 8 & 6 \\
\hline 14 & 37 & 14 & 14 \\
\hline 15 & 49 & 15 & 13 \\
\hline 16 & 25 & 8 & 9 \\
\hline 17 & 47 & 13 & 11 \\
\hline
\end{tabular}




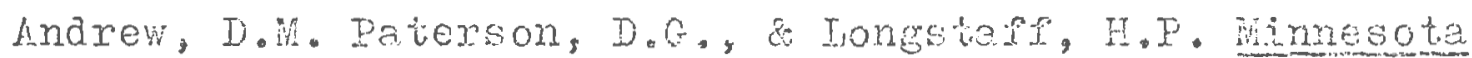
Clerical Test. Goryright 1933, The Psychologicel Corporation, New York, î. Y. Baker, J.W. The effects of four types of vicarious ageression on physiologica. and paychologicel arousai. Unpubished doctor's dissertation, West Virginia University, 1967. Bandura, A. \& Halters, R.H. Ageression. In Harold Stevenson (Fd.), Agression in child psychology, Chjcago, Illinois: Uilivexsity of Chicago Press, 1963. $364-41.5$.

Berkowitz, I, Aggression: A social psychological aralysis. New York: McGraw Hill Book Co., 1952.

Buss, A.H. The psycholory of aggression. New vork: tohn Viley \& Sons, 1961.

Buss, f.H. \& Durkee, An inventory for assessing different kinds of hostility. Journal of Consalting Isycholory, $1957,21,343-348$.

Buss, A.I., vurkee \& Baer, M. The measurement of hostjitty in clinicel situations. Jourmel of Abnosme and Social Psycholoz: $3.956,52,84-86$. Buss, A. H. Foliart, R. Role-playing ageression and tro catharsis hypothesis. Unpublished researci, 1953. Dollard, J., Loob, I.i., Miller, N.I., Mowrer, O.HI, \& Sears, r.r. Frustretion and agression. New Faven: yale University Fress, 1939. 
Feshbach, S. The drive-reducing functon of fantas beharior.

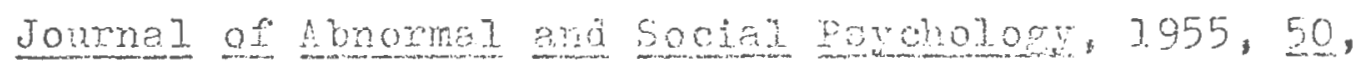
$3-1 I$.

Feshoach, S. The catharsjs hypothesis and some consequences of interaction with argressive and reutrel play objects. Journal of Iersonelity, 1956, 27, 449-462.

Feshbach, S. The stimulating vs. cathartic effects of a vicarjous aggressive activity. Paper read at Eastern Psychological Association meetings, 1958. Feshbach, S. The stimulating vs. vierious effectis of a vicarious acgressive activity. Ionme of Abnomal and Social Psychology, 1961, 63, 301 -.385. Feshbach, S. The function of aggression and regulation of aggressive arive. Psycholosicel Reyjeg, 1964, II, 257-272.

Gardner, G.E. Recreation's part in mental health. Recrestion, 1952, 45, $446-448$.

Heymann, G.M. Some relationships amone rostjilty, fantasy aggression and aggressive behavior. Inpunished doctor's dissertation. Michigan State University, 1955. Hornberger, R. The differential reduction of ageressive responses as a function of interpolated activities, 1959, Paper read at Amesicar Poychological Association. Hokanson E., Purgoss, M. \& Cohen, $\bar{M} . \bar{F}$ (Forida State University) Effect of displaced agression on systolic blocd pressure. Jourrel of Abnormal and Socie? Esychologv. $1963,67(3), 214-218$. 
Husman, B.F. Ageression in boxers and wrestlers as measured by projective techriace. Fesearch garterly of the American Associetjon of Heglth and Enysicel Education. $1955,26,421-425$.

Jensen, A.R. Aggression in fantasy and overt behavior. Psychological Mongeraphs, 1957, 71, whole No. 445. Kenny, D.T. An experimental test of the catharsis theory of aggression. Unpublished doetor's dissertation, Uriversity of Washington, 1952.

Menninger, V.C. Kecreation and mental health. Recreailon, $1948,42,340-346$.

Miller, I.C. Rejationships between fantasy agsiession and behavioral aggression. Unpublished doctor's ajssertation. Haxvard University, 1953.

Mussen, P.H. \& Naylor, H.K. The relationships between overt and fantasy aggression. Jourrial of Abnornal and Social Psychology, 1954, 49, 235-240. Pirojnikoff, L.A. Catharsis and the role of perceptual change in the reduction of hostility. Unpublished docton's dissextation. University of Texas, 1958.

Rosenbaum, M. \& DeCharms, K. Direct and vicariove reduction of hostility. Journal of Abnomal end Social Psycholocy, $1960,60,105-111$.

Ryan, $\mathrm{Y}$. The cathartic effect of vigorous notor activity or ageressive hehavior. Fesearch guteterny, 1970, 17, $542-551$. 
Siegal, A.m, Timmedjater fantesy ageression ard strength

of agemessive drive. Child Developnent, 1956, 27, $365-378$

Spielberger, C.D. Anyjety ard beharior. New York: Aoedemjc Press, 7966

Stone, A.A. The effect of Earctioned overt aggression on total instigation to aggressive responses. Unpublished honors thesis, Farvard University, 1950. Citeā ir D. McCleliand, Personality. New York: Holt, Rinehart \&: Winston, 1.951

Thibaut, J. \& Coules, T. The role of communication in the reduction of interpersonel hostility Journs 1 of Abnommal ard SociaI Psyonology, 1952, 47, 770-778. Zuckerman, M. The development of an Affeot Adjective Cneck Iist for the measurement of anxiety Journal of Consulting Psychology, I960, 24, 457-462.

Zuckermar, M., Lubin, B., Vogel, I. \& Velerius, Measurement of experimentaly induced effects. Journe of consulting Psychology, 1964, 28, 418-425.

Zuckermar, M. \& Iubin, B., Normative data for the Multipe Adjective Check Iist. Peychological Reports, 1965.

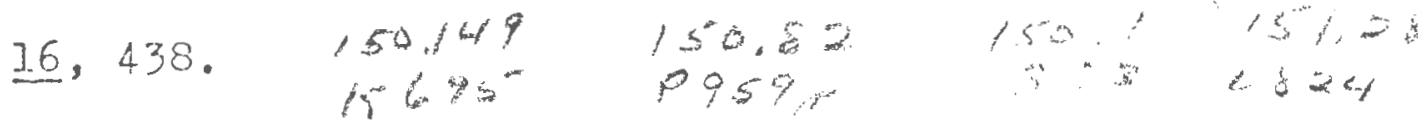

